\title{
Non-invasive genetic sampling of deer: a method for DNAextraction and genetic analysis from antlers
}

\author{
Muestreo genético no invasivo en ciervos: Un método para extracción de DNA y análisis \\ genético a partir de las astas
}

\author{
Carlos Venegas ${ }^{1}$, Valeria Varas ${ }^{1,2}$, Juan Pablo Vásquez ${ }^{1,3}$ \& Juan Carlos Marín ${ }^{1 *}$ \\ ${ }^{1}$ Laboratorio de Genómica y Biodiversidad, Facultad de Ciencias, Universidad del Bio-Bío, Chillán, Chile. \\ ${ }^{2}$ Instituto de Ciencias Ambientales \& Evolutivas, Facultad de Ciencias, Universidad Austral de Chile, Valdivia, Chile. \\ ${ }^{3}$ Departamento de Zoología, Facultad de Ciencias Naturales y Oceanográficas, Universidad de Concepción, Concepción, Chile. \\ *E-mail: jcmarin@ubiobio.cl
}

\begin{abstract}
We describe a non-invasive technique to isolate genomic DNA from connective tissue present in the antlers of deer of the genus Hippocamelus. This method is simpler and more effective than conventional more-destructive procedures which damage the collection material. This method is applicable to all cervids that annually regenerate their antlers.
\end{abstract}

KeYwords: conservation, genetic material, huemul, South America, taruca.

\section{RESUMEN}

Describimos aquí una técnica no-invasiva para aislar ADN genómico desde tejido conectivo presente en astas de ciervos del género Hippocamelus. Este método es más efectivo y simple que procedimientos convencionales que dañan el material de colección. Este método es aplicable a todos los cérvidos que renuevan anualmente sus astas.

Palabras clave: conservación, huemul, material genético, Sudamérica, taruca.

In recent decades biological studies have increasingly relied on the extraction of DNA from wide variety of tissues (Bosch et al. 2005). In particular, the genetic evaluation of species that are of conservation or management concern often require a reliable source of biological material for molecular analysis (Wasko et al. 2003). As such, population-scale studies are often limited by the difficulty in obtaining samples from sufficient numbers of individuals, especially when they have low population numbers, are difficult to find, and/or difficult to sample. It obtaining an appropriate number of samples, including non-invasive DNA samples, for population studies of endangered species whose value lies precisely in their population decline and high vulnerability.

Genetic analyses through molecular methods are often restricted by DNA availability. The quantity and quality of the DNA obtained from non-conventional sampling, which can be increased by PCR, is the first obstacle to overcome in population studies. The procedures to obtain DNA include the use of non-invasive sampling, which allows samples to be obtained without the need to anesthetize, modify, or take part from the individual directly (Morin et al. 1993; Wasko et al. 2003; Bosch et al. 2005). These provide a source of DNA sufficient not just for identifying species, but also for differentiating individuals and sexes.

In large mammals, DNA samples can be obtained from fluids, hair, and feces gathered in the field. In museums, the use of skins, bones, horns, and antlers can be a valuable source of non-invasive samples for DNA extraction. However, these types of samples usually provide DNA of low quantity, quality, and integrity, which makes the analysis of some molecular 
markers difficult, especially single-copy genes. In deer, different investigations have used the antlers of individuals as a source of DNA for genetic analysis (Wang \& Schreiber 2001; Ludt et al. 2004; Kuehn at al. 2005).

In southern South America, the genus Hippocamelus is represented by two extant species: the taruca, Hippocamelus antisensis, d'Orbigny, 1834, inhabiting the foothills of southern Peru, western Bolivia, north-western Argentina and northern Chile and the huemul, Hippocamelus bisulcus, Molina, 1978, distributed in the sub-Antarctic forest southern Chile.

The huemul, the southern-most Neotropical deer, is the only large herbivore found in the Sub-Antarctic Nothofagus forests of Chile and Argentina (Dellafiore \& Maceira 2001) and the periglacial scrub of the Patagonian steppe (Díaz \& Smith-Flueck 2000; CONAF-CODEFF 2001). Currently, there are restricted to only a few isolated populations. The Central Chile population of Nevados de Chillán - Laguna Laja $\left(36^{\circ}\right.$ $37^{\circ} \mathrm{S}$ ) is geographically separated by more than $500 \mathrm{~km}$ from the nearest population in Argentina (in Lanin National Park), which is more than $1,200 \mathrm{kms}$ from a second Chile population Southern Patagonia $\left(41^{\circ}\right.$ - 54 $4^{\circ}$ S) (Aldridge \& Montecinos 1998; López et al. 1998; Vila et al. 2006). As such, the current distribution is substantially lower than in the past by at least 50 \% (Perfaur et al. 1968; Drouilly 1983; López 2010). The huemul is listed as an endangered species by the book Red of threatened species (IUCN 2007) due to poaching, habitat loss and fragmentation, depredation and disturbance by domestic dogs, overgrazing and transmission of diseases by exotic livestock and isolation of their populations (Povilitis 1998; Smith-Flueck 2000; Serret 2001).

The taruca, similar in appearance, size and body structure, is often called the northern huemul. It is distributed along the Andes from the central-western portion of Peru southwards to the northeast of Argentina and a small population in the northeast Chile (Barrio 2010). Taruca inhabit relatively humid climates of the eastern Andes (Jungius 1974), as well as dry areas in the western Andes (Merkt 1985; Barrio, 1998). Generally, taruca are found above the tree line on mountain slopes characterized by rocky outcrops and cliffs with interspersed grassland (Jungius 1974; Merkt 1985; Barrio 1999), preferably with nearby water sources, small ravines, lagoons or marshes (Barrio 2010).

The taruca is classified as vulnerable in the red book of threatened species (IUCN 2008) due to reduced population size (an estimated $30 \%$ or original size) resulting from poaching and habitat reduction and fragmentation (Barrios 2010). The taruca is a high-profile charismatic species that symbolizes the threatened natural heritage of the Andes Mountains.

Robust and informed conservation efforts are needed to better understand past demographic history of both huemul and taruca. However, effective long-term data will depend on the development of more efficient tools to assess past population history and to monitor current populations, ideally through non-invasive sampling. Through the extraction of DNA from the horns of huemul and taruca and the use assessment of mitochondrial DNA and nuclear DNA genetic markers, we hope to significantly increase our understanding of past and present Hippocamelus species and populations and thus design more-effective conservation strategies and management of the species.

Deer antlers (Fig. 1a), which are made of real bone, are extensions of the skull. They are replaced annually in the males of most Cervidae (García et al. 1997). Annual renewal of deer antlers is the only case of mammalian appendage regeneration and represents true epimorphic regeneration (Li et al. 2009). Each spring, male deer produce a new set of antlers. As the antlers develop, they are covered with a thin sheath of "velvet" which supplies nutrients to the growing bone. During summer, the velvet falls off, leaving mature antlers made of dead bone. After mating season, the antlers fall off.

Antlers are a source of DNA source that, until now, has been rarely used for genetic analysis. The annual renewal of antlers would be a source of non-invasive samples of critical species with conservation issues like the huemul (Hippocamelus bisulcus) and the taruca (Hippocamelus antisencis).

The area between the antlers and the skull consists of connective tissue that is protected from decomposing. As such it is a excellent source of high molecular weight DNA, even after several years. Many studies have used antlers deposited in museums as a source of DNA. However, in most cases, this involves the partial destruction of the material through the pulverization of fragments of the antler (Taberlet et al. 1996; Hofreiter et al. 2001; Ludt et al. 2004; Bosch et al. 2005; Kuehn et al. 2005). Here we describe a non-invasive method of obtaining tissues from deer antlers deposited in museum collections or collected in the field that does not damage the antler and that allows the extraction of quality DNA.

Nine antlers of huemul and thirteen antlers of taruca were obtained from field sampling, museum collections, and private collections (Table 1) and were then cleaned and stored in sterile bags. The basal part of the antler was washed with distilled water. After drying, the ring of connective tissue that was adhered to the basal part of the shaft was removed with a sterile scalpel (Fig. 1b). Then, the tissue was collected in sterile eppendorf tubes and before extraction, the pieces were washed by adding $1 \mathrm{~mL}$ of $70 \%$ ethanol to the tube. The tube was vortexed for 1 minute with the pieces of connective tissue and ethanol. The alcohol was removed with 
a micropipette and the remaining tissue fragments in the tube were dried at $40^{\circ} \mathrm{C}$ or room temperature before extraction. DNA was extracted from 10 grams of the washed conjunctive tissue. The spraying was done with Pellet pestles. All samples were stored at $-70^{\circ} \mathrm{C}$ in the Laboratorio de Genómica y Biodiversidad, Departamento de Ciencias Básicas, Facultad de Ciencias, Universidad del Bío-Bío, Chillán, Chile. Total genomic DNA was extracted from the tissue using three methods: 1) a Wizard Genomic DNA Purification Kit (Promega, Madison, WI, USA); 2) digestion with proteinase $\mathrm{K}$, followed by phenolchloroform extraction and ethanol precipitation (Sambrook et al. 1989) and 3) sodium dodecyl sulfate-proteinase $\mathrm{KNaCl}$ extraction and alcohol precipitation (Maniatis et al. 1992).
Equal amounts of each sample were extracted using three methods and performed in triplicate. DNA quantity and quality were measured by reading the whole absorption spectrum (220-750 nm) and by electrophoresis $1 \%$ agarose gels. Additionally, each sample was quantified with a Qubit fluorometer. In addition to the precautions detailed in the antler sampling protocol described above, the main protection against contamination depends on the specificity of the primers. Even though the extraction of DNA from connective tissue was a mixture of DNA from a variety of organisms (for example, bacteria and fungi), species-specific primers designed for specific genes were used to amplify only DNA fragments of our species under study.
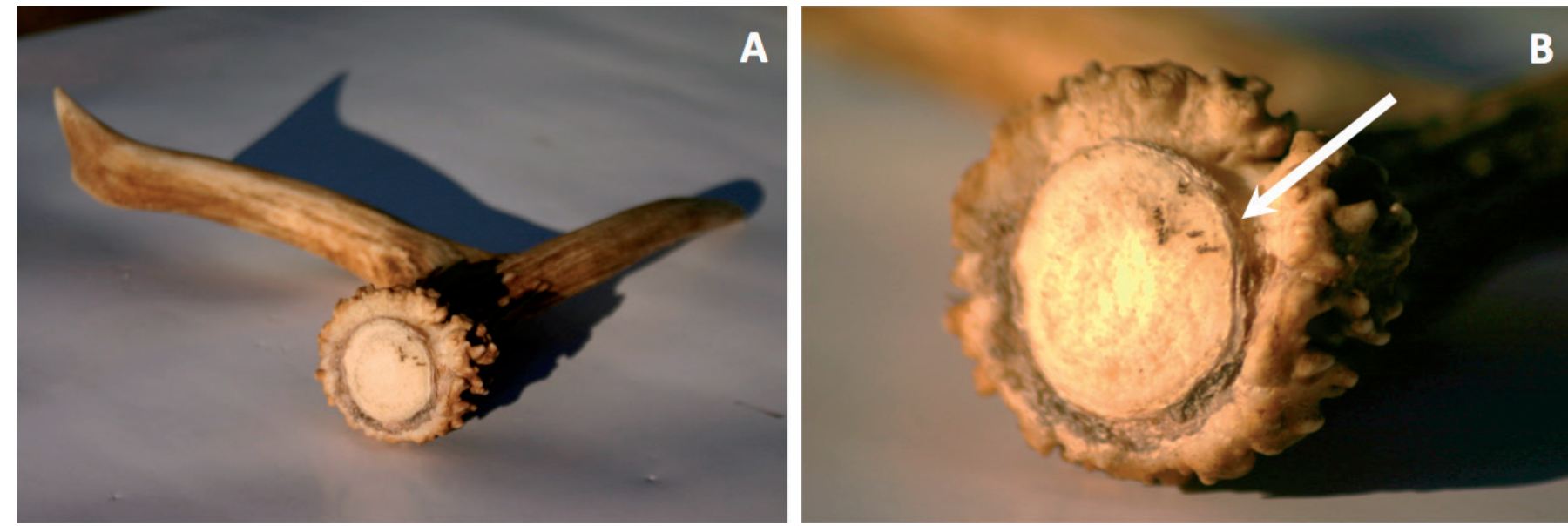

FIGURE 1. Side view of an antler of a male Hippocamelus bisulcus from Rio Simpson, Chilean Patagonia (a), view of the base area of the antler showing connective tissue with an arrow (b). / Vista lateral de un asta de Hippocamelus bisulcus macho de Río Simpson, Patagonia Chilena (a), vista de la base del asta, indicando con una flecha la presencia de tejido conectivo (b).

TABLE 1. Locality, geographic coordinates, and antler source: field sampling (f), museum collections (m), private source (p) and number of samples Hippocamelus samples. / Localidad, coordenadas geográficas y origen de las astas: muestreo de campo (f), colecciones de museos (m), fuentes privadas (p) y número de muestras de Hippocamelus.

\begin{tabular}{|c|c|c|}
\hline Localities & Geographic position & $\begin{array}{l}\text { Number of samples and } \\
\text { collection method }\end{array}$ \\
\hline \multicolumn{3}{|l|}{ Hippocamelus antisencis } \\
\hline Putre, Chile & $18^{\circ} 11^{\prime} 28^{\prime \prime} \mathrm{S}, 69^{\circ} 31^{\prime} 30^{\prime \prime} \mathrm{W}$ & 9 from private source \\
\hline Belén village, Chile & $18^{\circ} 29^{\prime} 51^{\prime \prime} \mathrm{S}, 69^{\circ} 31^{\prime} 34^{\prime \prime} \mathrm{W}$ & 4 from field samples \\
\hline \multicolumn{3}{|l|}{ Hippocamelus bisulcus } \\
\hline Nevados de Chillán, Chile & $36^{\circ} 50^{\prime} 52^{\prime \prime} \mathrm{S}, 71^{\circ} 15^{\prime} 28^{\prime \prime} \mathrm{W}$ & 1 from field samples \\
\hline Nahuel-Huapi Nacional Parck, Argentina & $40^{\circ} 47^{\prime} 58^{\prime \prime} \mathrm{S}, 71^{\circ} 34^{\prime} 35^{\prime \prime} \mathrm{W}$ & 2 from museum \\
\hline Lago Puelo Nacional Parck, Argentina & $42^{\circ} 08^{\prime} 18^{\prime \prime} \mathrm{S}, 71^{\circ} 39^{\prime} 37^{\prime \prime} \mathrm{W}$ & 1 from private source \\
\hline Mañihuales, Chile & $45^{\circ} 13^{\prime} 45^{\prime \prime} \mathrm{S}, 72^{\circ} 12^{\prime} 52^{\prime \prime} \mathrm{W}$ & 1 from field samples \\
\hline Rio Simpson Nacional Reserve, Chile & $45^{\circ} 36^{\prime} 07^{\prime \prime} \mathrm{S}, 72^{\circ} 12^{\prime} 52^{\prime \prime} \mathrm{W}$ & 3 from private source \\
\hline Los Glaciares Nacional Parck, Argentina & $49^{\circ} 37^{\prime} 15^{\prime \prime} \mathrm{S}, 72^{\circ} 55^{\prime} 95^{\prime \prime} \mathrm{W}$ & 1 from private source \\
\hline
\end{tabular}


To evaluate the success rate and quality of the extracted DNA, six pairs of primers were used to amplify $\sim 500 \mathrm{pb}$ from the first third of cytochrome b (Marín et al. 2007), and 500 and $\sim 600 \mathrm{pb}$ of the left and right domain of the mitochondrial Control Region, using huemul-specific primers (Marín et al. 2013). Amplification was performed in $50 \mu \mathrm{l}$ with $\approx 30 \mathrm{ng}$ genomic DNA, 1 reaction buffer (8 $\mathrm{mM}$ Tris- $\mathrm{HCl}(\mathrm{pH}$ 8.4), 20 $\mathrm{mM} \mathrm{KCl} \mathrm{(Invitrogen} \mathrm{Gibco,} \mathrm{Life} \mathrm{Technologies,} \mathrm{Invitrogen} \mathrm{Ltd.,}$ Paisley, UK), $2 \mathrm{mM} \mathrm{MgCl}$, $25 \mathrm{mM}$ each of deoxyguanosine triphosphate, deoxyadenosine triphosphate, deoxythymidine triphosphate and deoxycytidine triphosphate, $0.5 \mathrm{mM}$ each primer and $0.1 \mathrm{U} / \mu \mathrm{l}$ Taq polymerase (InvitrogenGibco, Life Technologies). Thermocycling conditions were: $95^{\circ} \mathrm{C}$ for 10 min, followed by $30-35$ cycles of $94^{\circ} \mathrm{C}$ for $45 \mathrm{~s}, 57-62^{\circ} \mathrm{C}$ for $45 \mathrm{~s}, 72^{\circ} \mathrm{C}$ for $45 \mathrm{~s}$, then $72^{\circ} \mathrm{C}$ for $5 \mathrm{~min}$. PCR products were purified using the GeneClean Turbo for PCR Kit (Bio101) following the manufacturer's instructions. Products were sequenced in forward and reverse directions using BigDye chemistry on an $\mathrm{ABI}$ Prism 377 or 3100 semiautomated DNA analyser. Geneious v.9.1.5 (Biomatters, Auckland, New Zealand) was used to align forward, reverse, and consensus sequences, and the alignments were rechecked by eye. Sequences were confirmed with two independent rounds of amplification and sequencing. GenBank accession codes for the alignments are KY420200-KY420384 and KY420385KY420569, respectively. From the huemul sequences of the Rio Simpson (RS) and Rio Bravo (RB) populations, genetic and haplotypic diversity were estimated.

Of all the samples $(N=39)$, DNA was extracted from 9 of the huemul samples and 13 of the taruca samples (Table 1). The quantity of DNA recovered from antlers' connective tissue with the three extraction methods was 0.9-13.4 $\mu \mathrm{g}$. Overall analysis of variance tests for differences by extraction method were not significant at $\mathrm{P}<0.005$ for all three experimental systems, but were significant at $\mathrm{P}<0.005$ between samples (Fig. 2).

From the antlers' DNA extracted from the huemul it was amplified and sequenced a fragment of $\sim 500-450 \mathrm{pb}$ and $\sim 600 \mathrm{pb}$, corresponding to the hypervariable region I and II from the control region (d-loop) of the mitochondrial DNA respectively. The size differences found in the hypervariable region I of huemules and tarucas has to do with the detection of a delection of $50 \mathrm{pb}$ in taruca, confirmed with sequences made in other tissues. The sampling also amplified the latest one positively. $\sim 500 \mathrm{pb}$ from the cytochromo $\mathrm{b}$ from both species. A trial made with seven specific markers microsatellites for the huemul (Shafer et al. 2012) amplified in the $60 \%$ of the sampling positively.

Among the 22 individuals analysed, we identified 22 variable positions segregated into 13 haplotypes, and total haplotype $(h)$ and nucleotide $(\pi)$ diversities of 0.33 and 0.871 , respectively. The hypervariable domain II was the most variable region in our data, presenting on average about twothirds of the polymorphisms. All sequences were deposited in GenBank under the accession numbers JN870923JN871197. The sequences obtained in the fragment of the gen Cytochrome b were used with sequences obtained from the other tissues in the construction of a phylogenetic tree.

In conservation biology, it is very important to carry out studies of the wild fauna and the environment that surrounds them, that is why in the area of conservation, the collection of samples by means of non-invasive methods of death is the key. These methods allow the extraction of DNA from the samples of species for the recognition of individuals or studies of molecular ecology, phylogenetics or phylogeography (de la Maza \& Bonacic 2013) in this way the use of non-invasive samples show a great advantage to obtain samples without causing stress to animals together with minimizes the risk that goes with sampling species with conservation issues, since these methods do not require the animal to be captured, or its environment disturbed. These methods also increase the number of samples per population in species with low numbers of individuals, or ones that are difficult to access because of habitat or behaviour (Taberlet \& Luikart 1999; Boch et al. 2005). The use of antlers as a source of DNA in population studies of Cervids has been regularly carried out in the past, due to the existence of considerable private and public collections; collections that grow every year thanks to the replacement of antlers that occurs in most cervids. One of the limitations of this type of technique is that these types of samples are not available the whole year in the field, and they restrict the analysis to the male population in the majority of the species, of deer populations, such as huemul and taruka, except for the reindeer, where males and females both show their antlers (Bubenik et al. 1997; Lincoln \& Tyler 1999; Holand et al. 2004). The annual shedding and replacement of the males' antlers provides a method to monitor the same population and individuals.

The use of the bone material from antlers for DNA extraction normally brings with it the loss of a significant portion of the antler; a method that, in most cases, does not produce enough quality DNA. The high amount of deterioration of the DNA extracted through these methods, as well as the presence of inhibitors and contamination with exogenous DNA, can lead to genotyping errors in the subsequent processes of amplification and sequencing (García et al. 1997; Bosch et al. 2005; Kuehn et al. 2005; Price et al. 2005) or simply the impossibility of amplifying fragments of medium size (>300 pb). The use of connective tissue, reported by us, although it does not show differences between the 
extraction methods, significant differences between samples were evident, presumably due to conservation differences and the antlers' age. Despite these, this method provides an unexplored advantage because it maintains the integrity of the antlers and gives DNA of higher quantity and quality. Since the body of antlers is composed of dead bone, obtaining cells for DNA extraction is more deficient than obtaining DNA from connective tissue. Moreover, the amount of cells per tissue volume is significantly higher in the connective tissue than in the rest of the antler's osseous structures (Colitti et al. 2005; Price et al. 2005).

The use of antlers has been important in the development of cellular and molecular studies (García et al. 1997; Barling \& Chong 1999; Colitti et al. 2005; Price et al. 2005), as well as in evolutionary, conservation, taxonomy, and systemic studies (Wang \& Schreiber 2001; Ludt et al. 2004). Our results show that the use of DNA extracted from the base of huemul and taruca antlers by PCR amplification of mitochondrial and nuclear sequences is of good quantity and quality (Table 2, Fig. 2). These fragments can be useful for studies of differentiation, geographic patterns, and historical aspects of both species, and even to formulate and support specific conservation recommendations. In the past, Ludt et al. 2004 extracted DNA from the antlers' osseous area and amplified the Cytochrome $b$ gene to study the molecular systematics of the family Cervidae. Kuehn et al. 2005, using the same tissue and gene, concluded that Megaloceros giganteus is more related to its modern regional counterpart, Cervus elaphus. These works show, however, low numbers of samples per species and partial destruction of the antlers in order to obtain usable DNA.
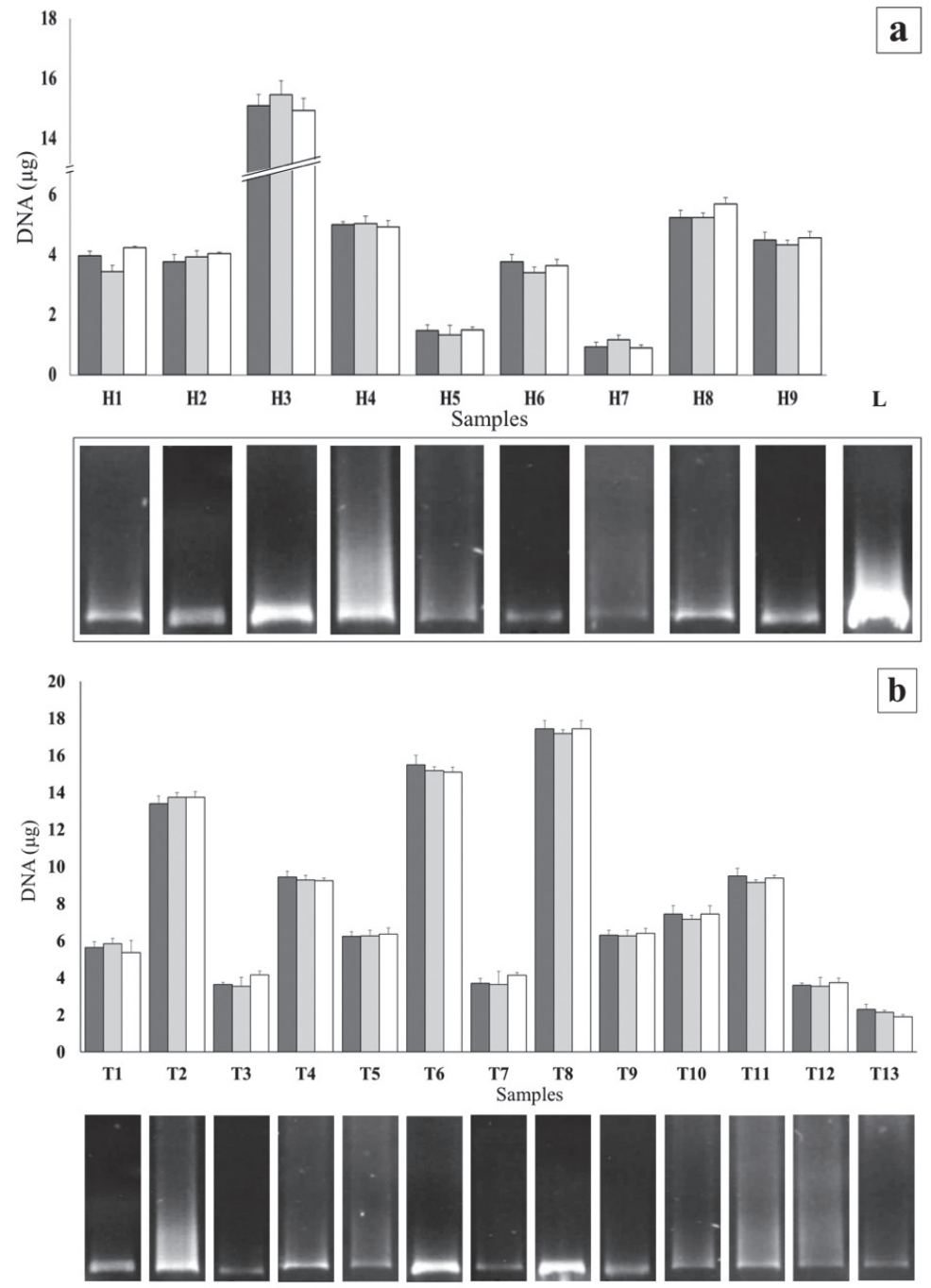

Figure 2. Quantity of DNA recovered from antlers' connective tissue in huemul (a) and taruca (b), using three extraction methods. Sample ID is indicated at the bottom. Lane L contains $100 \mu \mathrm{g}$ of DNA as the reference for normalization. / Cantidad de DNA recuperado del tejido conectivo de astas en huemul (a) y taruca (b), utilizando tres métodos de extracción. La identificación de la muestra se indica en la parte inferior. El carril L contiene $100 \mu \mathrm{g}$ de DNA como referencia para la normalización. 
TABLE 2. Amount of DNA extracted from antlers of huemul and taruca using different extraction methods. / Cantidad de DNA extraído de astas de huemul y taruka utilizando diferentes métodos de extracción.

\begin{tabular}{|c|c|c|c|c|c|c|c|}
\hline Huemul & & & & Taruca & & & \\
\hline Samples & Methods & $\begin{array}{l}\text { Average } \\
\text { (ng) }\end{array}$ & $\pm \mathrm{SD}$ & Samples & Methods & $\begin{array}{c}\text { Average } \\
\text { (ng) }\end{array}$ & $\pm \mathrm{SD}$ \\
\hline \multirow[t]{3}{*}{$\mathrm{H1}$} & $A$ & 3.967 & 0.153 & T1 & $A$ & 5.633 & 0.322 \\
\hline & B & 3.433 & 0.208 & & B & 5.833 & 0.289 \\
\hline & C & 4.233 & 0.058 & & C & 5,367 & 0.635 \\
\hline \multirow[t]{3}{*}{$\mathrm{H} 2$} & A & 3.767 & 0.252 & $\mathrm{~T} 2$ & A & 13.400 & 0.400 \\
\hline & B & 3.933 & 0.209 & & B & 13,733 & 0.252 \\
\hline & C & 4.033 & 0.058 & & C & 13.733 & 0.306 \\
\hline \multirow[t]{3}{*}{ H3 } & $A$ & 15.100 & 0.361 & T3 & $A$ & 3.633 & 0.116 \\
\hline & B & 15.467 & 0.451 & & B & 3.533 & 0.503 \\
\hline & C & 14.933 & 0.404 & & C & 4.167 & 0.208 \\
\hline \multirow[t]{3}{*}{$\mathrm{H} 4$} & A & 5.000 & 0.100 & T4 & A & 9.433 & 0.306 \\
\hline & B & 5.033 & 0.252 & & B & 9.267 & 0.252 \\
\hline & C & 4.933 & 0.208 & & C & 9.233 & 0.153 \\
\hline \multirow[t]{3}{*}{ H5 } & A & 1.467 & 0.208 & T5 & A & 6.233 & 0.252 \\
\hline & B & 1.333 & 0.306 & & B & 6.267 & 0.306 \\
\hline & C & 1.500 & 0.100 & & C & 6.367 & 0.322 \\
\hline \multirow[t]{3}{*}{ H6 } & A & 3.767 & 0.252 & T6 & A & 15.500 & 0.500 \\
\hline & B & 3.400 & 0.200 & & B & 15.167 & 0.208 \\
\hline & C & 3.633 & 0.208 & & C & 15.100 & 0.265 \\
\hline \multirow[t]{3}{*}{$\mathrm{H} 7$} & A & 0.933 & 0.153 & T7 & A & 3.700 & 0.265 \\
\hline & B & 1.166 & 0.153 & & B & 3.633 & 0.710 \\
\hline & C & 0.900 & 0.100 & & C & 4.133 & 0.153 \\
\hline \multirow[t]{3}{*}{$\mathrm{H} 8$} & $A$ & 5.233 & 0.252 & T8 & $A$ & 17.433 & 0.451 \\
\hline & B & 5.233 & 0.153 & & B & 17.167 & 0.208 \\
\hline & C & 5.700 & 0.200 & & C & 17.433 & 0.451 \\
\hline \multirow[t]{15}{*}{ H9 } & A & 4.500 & 0.265 & T9 & A & 6.300 & 0.265 \\
\hline & B & 4.333 & 0.153 & & B & 6.267 & 0.306 \\
\hline & C & 4.567 & 0.208 & & C & 6.400 & 0.265 \\
\hline & & & & T10 & A & 7.433 & 0.451 \\
\hline & & & & & B & 7.167 & 0.208 \\
\hline & & & & & C & 7.433 & 0.451 \\
\hline & & & & T11 & A & 9.500 & 0.400 \\
\hline & & & & & B & 9.133 & 0.153 \\
\hline & & & & & C & 9.367 & 0.153 \\
\hline & & & & T12 & A & 3.600 & 0.100 \\
\hline & & & & & B & 3.533 & 0.503 \\
\hline & & & & & C & 3.733 & 0.252 \\
\hline & & & & T13 & A & 2.300 & 0.265 \\
\hline & & & & & B & 2.133 & 0.116 \\
\hline & & & & & C & 1.900 & 0.100 \\
\hline
\end{tabular}


The present work demonstrates how DNA extraction from the base of the huemul and taruca antlers constitutes a source of genetic material not previously used and of potentially broad unimaginable applications. However, in some cases we obtained partially deteriorated DNA that could be related to the amount of time that the antlers were susceptible to environmental damage, or to the time and conditions of storage in the collections. We also did not evaluate if there were PCR inhibitory enzymes. However, it is possible that this factor affects all types of samples equally, and the presence of these inhibitors depends more on the origin of the sample than on the type of tissue. In spite of these potential impediments, antlers proved to be a reliable and useful source of DNA that would be a simpler and more effective source of DNA than the conventional procedures used with antlers and which damage the collection material and produce a lower yield.

\section{ACKNOWLEDGEMENTS}

This research was supported by FONDECYT, Chile Grant 1140785, 11080098, CONICYT PCHA/Magister Nacional/2014-22140806 and DID-UBB (082409_1/R). We are grateful to SAG and CONAF for collection permits, and Paulo Corti and Rodrigo López. Special thanks are due to Warren Johnson for useful support and English improvement.

\section{REFERENCES}

Aldridge, D., Montecinos, L. 1998. Avances en la conservación del Huemul (Hippocamelus bisulcus) en Chile. In: Valverde, V. (Eds) La conservación de la fauna nativa de Chile, Logros y perspectivas. Ministerio de Agricultura, CONAF, Chile 178: 133-149 pp.

Barling, P.M., Chong, K.W. 1999. The involvement of phosphohydrolases in mineralization: studies on enzymatic activities extracted from red deer antler. Calcified Tissue International 65: 232-236.

Barrio, J. 1999. Población y habitat de la taruca en la Zona Reservada Aymara-Lupaca, Perú. In: Fang, T.G., Montenegro O.L., Bodmer, R.E. (Eds) Manejo y Conservación de Fauna Silvestre en América Latina: 453460. La Paz, Bolivia.

Barrio, J. 2010. Taruka. Hippocamelus antisensis (d'Orbigny 1834). En: Barbanti, J., González, S. (Eds) Neotropical cervidology: biology and medicine of Latin American deer. Jaboticabal, Funep, Brazil. 393 p.

Bosch, M., Marmi, J., Ferrando, A., López-Giráldez, F., Andrés, O.,
Gracía-Franquesa, E., Ponsa, M., Kellermann, T., Guallar, B., Bisbal, F., Domingo-Roura, X. 2005. Genotipar sin capturar. Galemys 17: 81-102.

Bubenik, A.G., Schams, D., White, J.R., Rowell, J., Blake, J., Bartos, L. 1997. Seasonal Levels of Reproductive Hormones and Their Relationship to the Antler Cycle of Male and Female Reindeer (Rangifer tarandus). Comparative Biochemistry. Physiology 2: 269-277.

CONAF-CODEFF. 2001. Plan para la Conservación del Huemul del Sur (Hippocamelus bisulcus) en Chile. CONAF, Departamento Patrimonio Silvestre, Santiago. 40 pp.

Colitti, M., Allen, S.P., Price, J.S. 2005. Programmed cell death in the regenerating deer antler. Journal of Anatomy 207: 339-351.

De la Maza, M., Bonacic, C. 2013. Manual para el monitoreo de fauna silvestre en Chile. (Eds) Serie Fauna Australis. Facultad de Agronomía e Ingeniería Forestal, Pontificia Universidad Católica de Chile. 202 pp.

Díaz, N.I., Smith-Flueck, J.A. 2000. El huemul patagónico. L.O.L.A., Buenos Aires. 156 pp.

Dellafiore, C., Maceira, N. 2001. Los ciervos autóctonos de la Argentina y la acción del hombre. Grupo Abierto de Comunicaciones: 51-56 pp. Buenos Aires.

Drouilly, P. 1983. Recopilación de antecedentes biológicos y ecológicos del huemul chileno y consideraciones sobre su manejo. Boletín Técnico 5. Corporación Nacional Forestal, Santiago.

García, R.L., Sagidhi, M., Francis, S.M., Suttie, J.M., Fleming, J.S. 1997. Expression of neurotrophin-3 in the growing velvet antler of the red deer Cervus elaphus. Journal of Molecular Endocrinology 19: 173-182.

Hofreiter, M., Jaenicke, V., Serre, D., von Haeseler, A., Pääbo, S. 2001. DNA sequences from multiple amplifications reveal artifacts induced by cytosine deamination in ancient DNA. Nucleic Acids Research 23: 4793-4799.

Holand, O., Gjostein, H., Losvar, A., Kumpula, J., Smith, E.M., Roed, H.K., Nieminen, M., Eladji, B. 2004. Social rank in female reindeer (Rangifer tarandus): effects of body mass, antlers size and age. Journal of Zoology 263(4): 365-372.

IUCN. 2007. IUCN Red List of Threatened Species. URL: http:// www.iucnredlist.org.

IUCN. 2008. Hippocamelus antisensis. In: IUCN 2012. IUCN Red List of Threatened Species. Version 2012.2. URL: http:// www.iucnredlist.org. Acceded: March 27, 2013.

Jungius, H. 1974. Beobachtungen am Weisswedelhirsch und an anderen Cerviden in Bolivien. Zeitschrift Saugetierkunde 39: 373-383.

Kuehn, R., Ludt, C., Schroeder, W., Rottmann, O. 2005. Molecular Phylogeny of Megaloceros gigantus - the Giant Deer or Just a Giant Red Deer? Zoological Science 22: 1031- 
1044.

Li, C., Yang, F., Sheppard, A. 2009. Adults Stem Cells and Mammalian Epimorphic Regeneration-Insights from Studyng Annual Renewal of Deer Antlers. Current Stem Cell Research \& Therapy 4: 237-251.

Lincoln, A.G., Tyler, C.J. 1999. Role of oestradiol in the regulation of the seasonal antler cycle in female reindeer, Rangifer tarandus. Journal of Reproduction and Fertility 115: 167174.

López, R., Serret, A., Faúndez, R., Palé, G. 1998. Estado del conocimiento actual de la distribución del huemul (Hippocamelus bisulcus, Cervidae) en Argentina y Chile. Fundación Vida Silvestre Argentina (FVSA), World Wildlife Fund (WWF) y Comité Nacional pro Defensa de la Fauna y Flora (CODEFF), Concepción, Chile. 32 p.

López, R. 2010. Nevados de Chillán - Laguna de la Laja Wildlife Corridor: Promoting Huemul and Biodiversity Conservation. Survey of Meta-Population of Huemuls (Hippocamelus bisulcus) in North Zone Nevados de Chillán Mountains. Comité Nacional Pro Defensa de la Fauna y Flora (CODEFF) and Frankfurt Zoological Society (FZS). Concepción, Chile.

Ludt, C., Schroeder, W., Rottmann, O., Kuehn, R. 2004. Mitochondral DNA phylogeography of red deer (Cervus elaphus). Molecular Phylogenetics and Evolution 31: 1064-1083.

Maniatis, T., Fritsch, E.F., Sambrock, J. 1992. Molecular cloning. A laboratory manual. Cold Spring Harbour Laboratory Press, Cold Spring Harbour, NY.

Marín, J.C., Zapata, B., González, B.A., Bonacic, C., Wheleer, J.C., Casey, C., Bruford, M.W., Palma, R.E., Poulin, E., Alliende, M.A., Spotorno, A.E. 2007. Sistemática, taxonomía y domesticación de alpacas y llamas: nueva evidencia cromosómica y molecular. Revista Chilena de Historia Natural 80: 121-140.

Marín, J.C., Varas, V., Vila, A., López, R., Orozco-terWengel, P., Corti, P. 2013. Refugia in Patagonian fords and the eastern Andes during the Last Glacial Maximum revealed by huemul (Hippocamelus bisulcus) phylogeographical patterns and genetic diversity. Journal of Biogeography 40: 2285-2298.

Merkt, J. 1985. Social structure of Andean deer (Hippocamelus antisensis: Cervidae) in Southern Peru. MSci Thesis. University of British Columbia, Canada. 134 pp.

Morin, P.A., Wallis, J., Moore, J., Chakrabort, R., Woodruf, D. 1993. Non-invasive sampling and DNA amplification for paternity exclusion, community structure, and phylogeography in wild chimpanzees. Primates 34 (3): 347-356.

Perfaur, J.W., Hermosilla, F., Dicastri, F., González, R.S. 1968. Estudio preliminar de Mamíferos Silvestres Chilenos: Su Distribución, Valor Económico e Importancia Zoonótica. Revista de la Sociedad de Medicina Veterinaria, Chile 18 (1-2-3-4): 3-15.

Povilitis, A. 1998. Characteristics and conservation of a fragmented population of huemul Hippocamelus bisulcus in central Chile. Biological Conservation 86: 97-104.

Price, J.S., Allen, S., Faucheux, C., Althnaian, T., Mount, J.G. 2005. Deer antlers: a zoological curiosity or the key to understanding organ regeneration in mammals? Journal of Anatomy 207: 603-618.

Sambrook, J., Fritsch, E.F., Maniatis, T. (Eds) 1989. Molecular cloning: A laboratory manual. $2^{\text {nd }}$ Edition. Cold Spring Harbor Press, Cold Spring Harbor, NY.

Serret, A. 2001. El huemul: Fantasma de la Patagonia. Zagur y Urrutz Publications, Buenos Aires. 130 pp.

Shafer, B.A.A., Northrup, M.J., White, S.K., Boyce, S.M., Coté, D.S., Coltman, W.D. 2012. Habitat selection predicts genetic relatedness in an alpine ungulate. Ecology 6: 1317- 1329.

Smith-Flueck, J. 2000. La situación actual del huemul patagónico, pp 67-150. In: Díaz, N.I., Smith-Flueck, J. (Eds) El Huemul Patagónica. Un misterioso cérvido al borde de la extinción. Literature of Latin America, Buenos Aires, Argentina. $156 \mathrm{pp}$.

Taberlet, P., Griffin, S., Goossens, B., Questiau, S., Manceau, V., Escaravage, N., Waits, L. P., Bouvet, J. 1996. Reliable genotyping of samples with very low DNA quantities using PCR. Nucleic Acids Research 26: 3189- 3194.

Taberlet, P., Luikart, G. 1999. Non-invasive genetic sampling and individual identification. Biological Journal of the Linnean Society 68: 41-55.

Vila, A., López, R., Pastore, H., Faúndez, R., Serret, A. 2006. Current distribution and conservation of the huemul (Hippocamelus bisulcus) in Argentina and Chile. Mastozoología Neotropical 13: 263-269 pp.

Schreiber, S., Wang, M. 2001. The impact of habitat fragmentation and social structure on the population genetics of roe deer (Capreolus capreolus L.) in Central Europe. Heredity 86: 703-715.

Wasko, A.P., Martins, C., Oliveira, C., Foresti, F. 2003. Nondestructive genetic sampling in fish. An improved method for DNA extraction from fish fins and scales. Hereditas 138: 161-165.

Received: 22.12.2017

Accepted: 17.01.2020 